\title{
SISTEM PENDUKUNG PENGAMBILAN KEPUTUSAN KLINIS DALAM PEMBERIAN TERAPI ANTIBIOTIK YANG RASIONAL
}

\author{
Suharyanto \\ Bagian Ilmu Penyakit Dalam Fakultas Kedokteran \\ UGM/ RSUP Dr. Sardjito \\ Email: prharyjo2003@yahoo.com \\ Rizka Humardewayanti Asdie \\ Bagian Ilmu Penyakit Dalam Fakultas Kedokteran \\ UGM/ RSUP Dr. Sardjito \\ Email: rizkaipd2013@gmail.com
}

\begin{abstract}
ABSTRAK
Pemilihan terapi antibiotik yang rasional pada penyakit infeksi akan memperbaiki simptom klinis secara lebih cepat, efisien dibandingkan dengan terapi yang tidak tepat atau tidak sesuai. Klinisi harus meningkatkan keahlian dalam penggunaan antibiotik yang rasional pada penyakit infeksi yang ringan atau berat dan pada penyakit yang disebabkan oleh virus. Terapi antibiotik yang rasional mencegah terjadinya resistensi antibiotik. Sistem pendukung pengambilan keputusan klinis (SPKK) akan meningkatkan penggunaan antibiotik yang rasional. Penelitian ini mengembangkan prototipe SPKK untuk mendukung pengambilan keputusan penggunaan antibiotik yang rasional. Desain penelitian ini menggunakan pendekatan action research. Pengembangan sistem dengan prototiping menggunakan rule based dengan format "IF < gejala $>$ THEN < terapi > ". Pengujian system dilakukan dengan membandingkan output dari klinisi dan dari sistem. Hasil evaluasi system terdapat 50 data kuesioner yang diberikan pada klinisi dengan hasil yang sesuai dengan guideline adalah output dari klinisi 35 (70\%) dan output system 49 $(98 \%), X^{2}=0,087, p=0,768$. Pada hasil atas menunjukkan bahwa sistem memiliki performan yang baik.
\end{abstract}

Kata kunci: diagnosis, rasional, terapi antibiotik, rule-based "IF THEN".

\section{ABSTRACT}

The selection of rational antibiotics therapy for infectious diseases will improve of the clinical symptoms more quickly and efficient compared with delayed or inappropriate therapy. The clinicians must increase of knowledge about rational antibiotic using for the mild or severe bacterial infection and the disease caused by a virus. The rationale antibiotic therapy will protect of the resistant antibiotics bacterial. The Clinical Decision Support System will help to increase of the rational antibiotic therapy by Clinician. This study developed a prototype GDSS to support decision making of rational antibiotics therapy. This study use action research approach. Development of system with prototyping methods and use rule-based system with format of "IF <symptoms> THEN <therapy>. The evaluation of systems by comparing the output of clinician with the output system. The results of evaluation are 50 quessionnary data from clinician, the correct result $35(70 \%), X^{2}=0,087, p=0,768$. The result of output system and clinician show that the system has good performance to support decision making of antibiotics rational used.

Keywords: diagnostic, rational, antibiotic therapy, rule-based "IF THEN".

\section{PENDAHULUAN}

Terapi antibiotik empiris secara tepat akan memperbaiki gejala klinis lebih cepat dan outcome yang lebih baik. Klinisi terkadang harus menginisiasi antibiotik untuk masalah klinis apakah penyebabnya infeksi ini bakteri atau virus, apakah infeksi ini gejalanya ringan ataukah berat. Pemberian antibiotik memerlukan pendekatan dan pertimbangan sehingga tidak terjadi kesalahan dalam pemberian antibotik.

Pemberian antibiotik yang tepat akan sangat membantu dalam kesembuhan pasien dan efektivitas biaya. Pemberian antibiotik yang tidak tepat akan menimbulkan berbagai efek yang merugikan antara lain: kemampuan membunuh bakteri kurang, kecepatan perbaikan klinis menurun, biaya yang meningkat dan yang paling membahayakan adalah terjadinya resistensi bakteri terhadap antibiotik.

Penggunaan antibiotik di beberapa Negara maju dan negara berkembang termasuk di Indonesia masih banyak dilakukan secara tidak rasional sehingga akan banyak menimbulkan kerugian pada pasien 
dan meningkatnya kejadian resistensi antibiotik pada mikroba yang sangat membahayakan. Di Amerika Serikat, antimikroba termasuk klas obat kedua yang paling sering digunakan setelah obat penyakit jantung atau kardiovaskuler. Penggunaan antibiotik di rumah sakit sekitar 25\% - 40\% dari jumlah pasien. Jumlah penggunaaan antibiotik sekitar $25 \%$ dari total pemakaian obat. Penggunaan antibiotik yang diresepkan oleh tenaga medis pada praktek swasta sekitar 15\%. Beberapa penelitian di Amerika Serikat menunjukkan sekitar 50\% penggunaan antibiotik tidak rasional atau tidak tepat (tidak berdasarkan indikasi, kesalahan obat, salah dosis atau durasi waktu) [1].

Pada penelitian Sutrisno (2013) dilakukan audit terhadap penggunaan antibiotik pada pasien pneumonia dengan hasil didapatkan jumlah pemakaian antibiotik yang tidak rasional mencapai $68 \%$ [2]. Pemakaian antibiotik yang tidak tepat saat ini banyak terjadi sehingga dapat mengakibatkan kolonisasi bakteri patogen yang resitensi terhadap antibiotik. Koloni bakteri yang resisten terhadap antibiotik bila menginfeksi individu akan menimbulkan masalah yang sangat merugikan. Pasien yang mengalami superinfeksi akan sulit dilakukan terapi dengan antibiotik yang sudah biasa digunakan karena bakteri sudah resisten. Hal ini mengakibatkan pasien memerlukan perawatan inap yang lebih lama, biaya yang lebih tinggi dan memiliki risiko kematian yang tinggi [3].

Salah satu upaya untuk mengurangi kejadian penggunaan antibiotik yang tidak rasional maka perlu dirancang sistem yang dapat membantu dalam memberikan dukungan klinis dalam pemberian antibiotik. Sistem ini diharapkan dapat membantu klinisi dalam memberikan terapi antibiotik sacara tepat agar tidak terjadi peningkatan bakteri yang resisten antibiotik. Resistensi bakteri terhadap antiniotik akan menghasilkan kolonisasi patogen yang tahan terhadap antibiotik sehingga jika bakteri menginfeksi pasien (mengalami superinfeksi) maka pasien memerlukan perawatan rawat inap lebih lama, biaya lebih tinggi dan angka mortalitas yang tinggi $[3,4,5]$.

Pemilihan antibiotik yang tepat pada penyakit infeksi akan memperbaiki gejala klinis lebih cepat, efisien dan mempengaruhi outcome pada pasien. Sebaliknya terapi antibiotik yang tidak tepat akan menimbulkan resistensi kuman patogen yang sangat merugikan bagi pasien. Hal yang penting sebagai pertimbangan dalam pemberian antibiotik adalah: 1). Orang-orang yang sakit parah (seriously ill) yang memerlukan spektrum antibiotik yang mencakup untuk patogen-patogen yang resisten. 2). Penggunaan antibiotik harus diminimalkan dan tidak digunakan pada pasien yang tidak memerlukan antibiotik misalnya pada infeksi virus. Dua hal ini dapat memperpanjang usia antibiotik sehingga tidak memerlukan antibiotik yang baru, aman dan efektif [6,7].

Pemberian antibiotik harus dipertimbangkan efek yang optimal dari antibiotik. Ada 10 Pertanyaan yang harus dijawab sebelum memberikan terapi antibiotik secara bijaksana yaitu:

1. Apakah antibiotik memang dibutuhkan?

2. Sebelum antibiotik diberikan apakah spesimen pasien klinik sudah terambil, diperiksa dan dikultur?

3. Organisme apa yang diperkirakan sebagai penyebab?

4. Antibiotik apa yang harus dipilih? Apakah bisa menggunakan antibiotik lainnya?

5. Apakah bisa diberikan terapi kombinasi antibiotik dan ada diindikasi?

6. Apakah ada faktor host?

7. Apa rute pemberian yang terbaik pada pemberian antibiotik?

8. Berapa dosis yang tepat digunakan untuk terapi?

9. Apa harus diakukan modifikasi terapi setelah ada hasil pemeriksaan kultur?

10. Berapa lama durasi terapi yang optimal?

Pemberian antibiotik harus memperhatikan 10 pertanyaan diatas sebagai pedoman bagi klinisi dalam memberikan antibiotik secara tepat. Durasi optimal terapi antibiotik yang tepat belum diketahui secara pasti, pada beberapa penyakit sudah diketahui misalnya minimum 6 minggu pada terapi osteomielitis atau selama 10-14 hari pada peritonitis dan pada TB paru 6 bulan. Sangat penting bagi klinisi dalam memberikan terapi antibiotik pada pasien secara adekuat dan dalam waktu yang tidak lama [7,8,9].

Kejadian resistensi antibiotik pada bakteri merupakan hal yang harus dipertimbangkan dalam pemberian antibiotik. Saat ini diketahui bahwa obat antibiotik berspektrum luas digunakan secara berlebihan (cephalosporin generasi ketiga dibandingkan cephalosporin generasi pertama). Hal ini dapat menimbulkan kolonisasi individu dengan bakteri yang resisten terhadap generasi ketiga dibandingkan generasi pertama cephalosporin. Pada pasien yang terinfeksi organisme resisten antibiotik ini akan mengalami keadaan yang merugikan karena memerlukan durasi rawat inap lebih lama, biaya perawatan yang lebih besar dan risiko kematian mengalami peningkatan $[3,10,11,12,13]$.

Pemanfaatan SPKK telah banyak terbukti dapat membantu dokter merawat pasien menjadi lebih baik [14]. Penambahan informasi yang relevan akan meningkatkan kemampuan SPKK menjadi lebih 
baik dalam memberikan dukungan pengambilan keputusan dan dapat menjadi alat pendidikan yang efektif untuk memperbaiki perilaku dokter [15]. Sistem pendukung keputusan klinis dapat meningkatkan kinerja klinisi dan memiliki efek yang baik pada pasien [16]. Sistem pendukung keputusan klinis aman digunakan, efektif, meningkatkan kualitas dan kontrol inisiasi pengobatan oleh dokter pada saat menjalani training.[17]. Penggunaan SPK dapat membantu meningkatkan kemampuan dokter dalam melakukan perawatan pasien dan memfasilitasi screening berkonsultasi dengan spesialis [18].

\section{METODOLOGI PENELITIAN}

Desain penelitian adalah action research dengan melibatkan partisipan yang terdiri: 1 dari akademisi, dokter spesialis penyakit dalam konsultan infeksi 1 orang dan 1 orang teknisi. Pengembangan sistem berbasis knowledge dengan rule based system IF THEN. Proses pemilihan antibiotik didasarkan pada basis pengetahuan hasil kompromi dari ahli (pengambil keputusan) dan guideline. Metode pengembangan sistem dengan membuat prototipe. Pengujian system dengan melakukan uji alpha untuk mengetahui aspek fungsional sistem. Pengumpulan data dilakukan dengan kuesioner pada klinisi.

\section{HASIL DAN PEMBAHASAN}

\subsection{Analisis Kebutuhan dan Perancangan Sistem}

Pengembangan sistem dilakukan dengan melakukan analisis kebutuhan sistem. Kebutuhan sistem untuk perancangan ini adalah perangkat keras dan perangkat lunak untuk perancangan sistem. Kebutuhan hardware saat ini sudah standart. Pengembangan sistem dilakukan dengan melibatkan peranan dan kerja sama dari anggota tim yaitu: dokter spesialis penyakit dalam 1 orang yang berperan dalam memberikan aturan dalam mendiagnosis dan mengevaluasi sistem yang dikembangkan, klinisi 1 orang sebagai sumber informasi dalam penggunaan standar terapi pelayanan kesehatan dan peneliti yang berperan dalam pengumpulan data, identifikasi kebutuhan sistem, perancangan antarmuka, database dan pemrograman sistem. Evaluasi sistem dilakukan oleh anggota tim sesuai peranan masing-masing.

Pengembangan sistem sangat diperlukan untuk memenuhi kebutuhan user dalam menyelesaikan masalah. Langkah awal pengembangan sistem adalah analisis kebutuhan sistem dengan mengidentifikasi proses-proses dan masalah-masalah yang ada. Analisis kebutuhan sistem berhubungan dengan input, proses, output, dan user interface sistem yang akan dikembangkan.

Semua data kebutuhan sistem diperoleh dari surve, hasil wawancara dengan dokter spesialis penyakit dalam konsultan penyakit infeksi, kepustakaan dan guideline. Kebutuhan-kebutuhan dalam pengembangan SPKK baik perangkat keras, perangkat lunak, database, antarmuka, rule base harus sesuai kebutuhan user [19]. Kebutuhan yang diperlukan dalam pengembangan sistem sebagai berikut:

Pada pengembangan sistem diperlukan data-data input sebagai masukan sistem yang diproses menghasilkan output. Data-data tersebut dihasilkan dari wawancara, survey, kepustakaan, guideline dan sumber lain yang diperlukan. Kebutuhan data-data dalam pengembangan sistem ini antara lain:

1. Data pengguna sistem, seperti: username, password.

2. Data pasien, seperti: kode pasien, nama pasien, jenis kelamin, alamat, pekerjaan dan diagnosis.

3. Data gejala seperti: kode gejala, nama gejala dan keterangan.

4. Data hasil pemeriksaan laboratorium, seperti: kode pemeriksaan, pemeriksaan laboratorium dan keterangan.

5. Data hubungan gejala, hasil laboratorium, diagnosis dan penggunaan antibiotik.

6. Preferensi berdasarkan rule base dengan format "IF THEN" .

Semua komponen sistem, perangkat keras dan perangkat lunak akan diintegrasikan untuk melakukan proses-proses sistem untuk mendukung pengambilan keputusan sehingga lebih cepat dan cermat. Setelah semua komponen sistem dan coding selesai, dilakukan uji coba sistem mulai dari pengujian struktur, urutan prosedur, rule, instruksi-instruksi, tampilan antarmuka, link dan koneksi database.

Output yang akan dihasilkan oleh sistem terdiri dari informasi-informasi yang berhubungan dengan penyakit infeksi antara lain:

1. Informasi gejala-gejala penyakit.

2. Informasi hasil laboratorium.

3. Informasi penggunaan antibiotik.

Sistem dikembangkan menggunakan 2 model antarmuka sebagai media beriteraksi antara user dengan sistem yaitu: Yes/No Question. Model ini digunakan untuk kemudahan user dalam berinteraksi 
dengan sistem. User dapat memilih memilih "Ya" atau "Tidak" sesuai dengan pernyataan pada sistem. Model yang lain adalah Option dialog yang terdiri dari menu-menu berbentuk pohon hirarki untuk memilih menu-menu yang ada dalam sistem [20]. Kedua model ini dipilih sebagai antarmuka sistem dengan alasan bahwa:

1. Kedua model relatif mudah digunakan oleh user.

2. Model menu digunakan, karena sistem memiliki proses yang memiliki beberapa subproses.

3. Model Yes/No Question digunakan karena sistem yang dikembangkan membutuhkan input pilihan "Ya" atau "Tdk" dari user. Bila user memilih "Ya" maka sistem akan memberi skore "1" dan bila memilih "Tdk" sistem akan memberikan skore "0" serta nama gejala akan dihilangkan sehingga sistem hanya memunculkan gejala-gejala yang ditemukan saja. Model ini digunakan untuk memilih kondisi yang ditemukan pada pasien. Pada sistem ini menggunakan beberapa objek sebagai media pemilihan seperti textbox dan objek untuk pilihan seperti radiobutton atau combobox [21].

Knowledge base (basis pengetahuan) merupakan kumpulan pengetahuan yang terdiri dari fakta, rules, konsep, teori, metode, prosedur, heuristik, dan relasi. Basis pengetahuan merupakan informasi yang terorganisir dan teranalisa, mudah dimengerti dan dapat diaplikasikan dalam pengambilan keputusan [22].

Salah satu cara merepresentasikan knowledge (pengetahuan) adalah menggunakan rule. Rule dengan struktur IF/THEN sebagai logika untuk menghubungkan informasi pada IF yang dikenal sebagai premis, dengan informasi dalam bagian THEN. Gabungan rule yang saling berkaitan disebut rule set [22,23]. Format umum rule sebagai berikut:

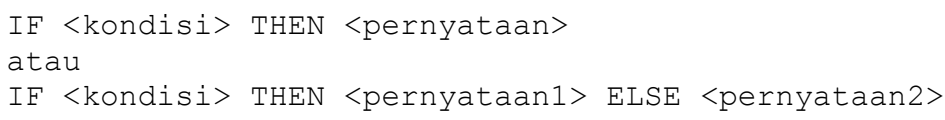

\subsubsection{Inference engine}

Inference engine (mesin inferensi) merupakan pengolah pengetahuan sebagai tiruan cara berpikir seorang pakar. Mesin inferensi memproses informasi yang diberikan dan menggunakan pengetahuan dalam knowledge base untuk menarik kesimpulan (menentukan diagnosis dan terapi) [22,23]..

\subsubsection{Langkah-langkah dalam proses pemilihan antibiotik}

Dalam menentukan diagnosis dan terapi antibiotik maka dilakukan langkah-langkah berdasarkan rule bases "IF THEN" dengan beberapa langkah. Proses pembuatan rule dimulai dengan menentukan kriteria dan proses diagnosis. Nilai 0 bila pernyataan salah (Tidak) dan pemberian nilai 1 (Ya) jika pernyataan bernilai benar. Berdasarkan kriteria penggunaan antibiotik pada penyakit tertentu maka akan terdiri dari gejala-gejala yang bernilai benar dan ada yang bernilai salah. Rule dalam sistem ini menggabungkan gejala-gejala yang benilai benar dan bernilai salah untuk menentukan proses selanjutnya dari sistem [22,23]. Rule base yang digunakan dalam sistem untuk menentukan diagnosis, dan pemberian antibiotik maka secara garis besar dibuat format seperti dibawah ini:

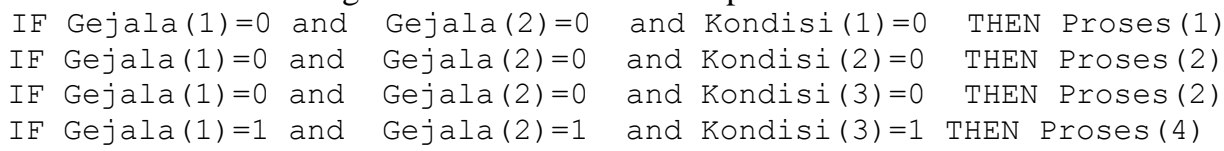

Rule base diatas dapat dijelaskan melalui susunan logika dari pola berpikir seorang ahli dalam menentukan diagnosis penyakit dan antibiotik yang paling rasional. Pola pemikiran dari ahli tersebut dapat disusun dengan seperti dibawah:

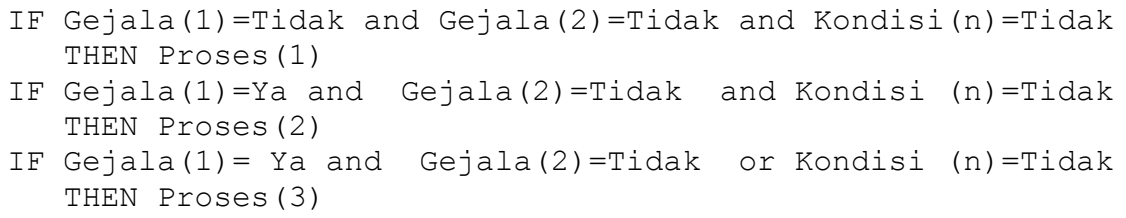


Pada logika diatas dapat diketahui bahwa bila gejala 1, gejala 2 dan gejala 3 bernilai (0) atau tidak maka sistem akan menentukan kombinasi nilai yang ada untuk menentukan proses-proses diagnosis dan pemberian antibiotik untuk penyakit yang dialami pasien.

\subsection{Pengujian Sistem}

Pengujian sistem untuk mengetahui apakah sistem dapat dioperasikan dengan baik. Pengujian awal sistem dilakukan oleh klinisi secara simulasi dengan memasukan gejala-gejala penyakit dan sistem memberikan output dan hasil dihitung prosentase yang sesuai dengan guideline. Pengujian validitas sistem dengan membandingkan hasil yang diberikan oleh klinisi dengan hasil output dari sistem. Pengujian dilakukan dengan input data dari kuesioner dari klinisi dan output dari sistem seperti tabel 1.

Tabel 1. Data pengujian sistem berdasarkan input dari kuesioner klinisi

\begin{tabular}{llrrrr}
\hline \multirow{2}{*}{ Variabel } & \multicolumn{2}{c}{ Sistem } & \multicolumn{2}{c}{ Total } \\
\cline { 3 - 4 } Klinisi & Benar & 35 & 0 & 35 \\
& Salah & 14 & 1 & 15 \\
\multirow{2}{*}{ Total } & & 49 & 1 & 50 \\
\hline
\end{tabular}

Pengujian dilakukan dengan 50 keusioner pada tiap guideline dengan hasil kesesuaian diagnosis dari klinisi dengan guideline sebesar 35 (70\%) dan guideline dan output sistem 49 (98\%) sesuai kedua guideline yang menunjukkan bahwa sistem memiliki validitas untuk memberikan dukungan pengambilan keputusan bagi klinisi.

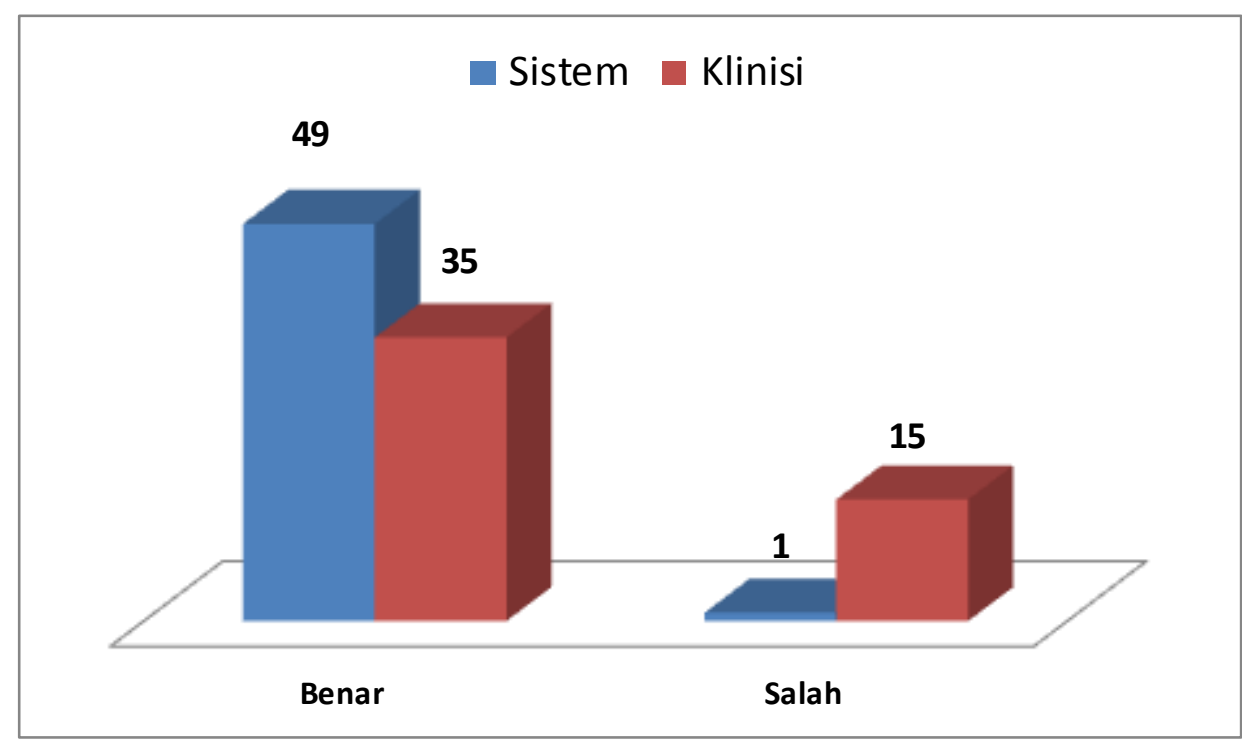

Gambar 1. Perbandingan jumlah hasil output dari Klinisi dengan sistem

Pada gambar 2. Menunjukkan bahwa output dari sistem adalah 49 (98\%) sedangkan hasil dari klinisi $35(70 \%)$. Hal ini menunjukkan bahwa sistema memiliki output yang lebih baik dari klinisi sehingga dapat digunakan untuk memberikan dukungan dalam penggunaan antibiotik secara rasional. 
Tabel 2. Perbandingan hasil diagnosis dari Klinisi dengan Sistem

\begin{tabular}{|c|c|c|c|c|c|c|c|}
\hline \multirow{2}{*}{\multicolumn{2}{|c|}{ Variabel }} & \multicolumn{2}{|c|}{ Sistem } & \multirow{2}{*}{\multicolumn{2}{|c|}{$X^{2}$}} & \multirow{2}{*}{\multicolumn{2}{|c|}{$\begin{array}{c}95 \% \text { CI } \\
\text { Lower Upper }\end{array}$}} \\
\hline & & Benar & Salah & & & & \\
\hline \multirow[t]{2}{*}{ Klinisi } & Benar & 35 & 0 & 2.381 & $0,300 *$ & 0,936 & 1.227 \\
\hline & Salah & 14 & 1 & & & & \\
\hline \multicolumn{8}{|c|}{$\begin{array}{l}\text { Catatan: } \\
\text { *. Uji Fisher Exact }\end{array}$} \\
\hline $\begin{array}{l}\text { Klinisi } \\
\text { Sistem }\end{array}$ & $\begin{array}{l}\text { : Teno } \\
\text { : Siste }\end{array}$ & $\begin{array}{l}\text { ehatan (Dok } \\
\text { g dikembang }\end{array}$ & & & & & \\
\hline
\end{tabular}

Dari tabel di atas dapat diketahui bahwa kinerja sistem berdasarkan guideline adalah $98 \%$ dibandingkan dengan hasil diagnosis klinisi dengan hasil kinerja berdasarkan guidelline adalah $70 \%\left(\mathrm{X}^{2}=\right.$ 2,381; $\mathrm{p}=0,300)$. Hasil penelitian ini menunjukkan bahwa sistem dapat digunakan untuk memberikan dukungan bagi klinisi untuk memberikan antibiotik pada pasien secara tepat. Pengembangan sistem ini diharapkan dapat dilanjutkan dengan memperbaiki sistem sehingga menjadi lebih baik. Penelitian yang dilakukan oleh Weber (2007) menghasilkan sistem pendukung keputusan klinis dengan reliabilitas dan validitas sistem 95\% $( \pm 3 \%)$ hal ini memiliki hasil yang telah dikembangkan saat ini [24]. Penelitian Murthy (2008) membandingkan kinerja sistem SCAR dalam menginvestigasi prediksi preoperative dibandingkan dengan perawat. Hasil pengujian system adalah sensitivitas 91,5\% dan spesifisitas 82,7\%. Pengujian dengan metode McNemar's test menghasil nilai $0,0455(\mathrm{p}=0,8312)$ dan $0,05(\mathrm{p}=0,8231)$ dan pada penggabungan kemampuan perawat yang direkomendasi OSCAR memiliki sensitivitas sampai $98,2 \%[25]$.

\section{KESIMPULAN}

Pengembangan sistem telah dilakukan dan sistem memiliki performa yang baik untuk mendukung pengambilan keputusan dalam penggunaan antibiotik yang rasional.

\section{DAFTAR PUSTAKA}

[1] Betts, Robert F., et.al., (2003). Principles of Antibiotik Use. Reese \& Betts': A Practical Approach to Infectious Diseases. 5th Edition. Lippincott Williams \& Wilkins.

[2] Sutrisno, E. (2013). Impact Of Irrational Antibiotik Therapy To Hospital Cost Of Care Of Pneumonia Inpatients In Dr. Sardjito Hospital. Thesis. Medical Faculty of Gadjah Mada University.

[3] Tunger, O., Karakaya, Y., Cetin, C.B., Dinc, G., Borand, H.,2009. Rational antibiotik use. J Infect Dev Countr 3.2,88-93

[4] McCue J. D.,1999. Antibiotik Use in the Elderly: Issues and Nonissues. Clinical Infectious Diseases. 28,750-2.

[5] Stalam, M, Kaye, D., 2004. Antibiotik agents in the elderly. Infect Dis Clin N Am. 18, 533-549

[6] Chambers, H.F., (2003). Bactericidal vs. Bacteriostatic Antibiotik Therapy: A Clinical Mini-Review. Vol.VI Issue 4 October. Published by National Foundation for Infectious Diseases 4733 Bethesda Avenue, Suite 750, Bethesda 
[7] Herring, A.R., Williamson, J.C., 2007. Principles of Antimicrobial Use in Older Adults. Clin Geriatr Med 23, 481-497

[8] Tunger, O., Karakaya, Y., Cetin, C.B., Dinc, G., Borand, H., 2009. Rational antibiotik use. J Infect Developing Countries; 3.2,88-93.

[9] Mehrotra, R., De Gaudio, R., Palazzo, M., 2004. Antibiotik pharmacokinetic and pharmacodynamic considerations in critical illness. Intensive Care Med, 30:2145-2156

[10] Roberts, J.A. , Lipman, J., 2009. Pharmacokinetic issues for antibiotiks in the critically ill patient. Crit Care Med., 37, 3

[11] Matuszkiewicz-Rowińska, j., Małyszko, J., Wojtaszek,E., Paweł Kulicki, P. (2012). Dosing of antibiotiks in critically ill patients:are we left to wander in the dark? Polskie Archiwum Medycyny Wewnętrznej; 122.12

[12] Cathrine Mc Kenzie., 2011. Antibiotik dosing in critical illness. J Antimicrob Chemother; 66 Suppl 2: ii25-ii31.

[13] Betts, Robert F.; Chapman, Stanley, W., , Robert, P. L. 2003. Principles of Antibiotik Use. Reese \& Betts': A Practical Approach to Infectious Diseases, 5th Edition. Lippincott Williams \& Wilkins.

[14] Payne, T. H. (2000). Computer Decision Support Systems. Chest;118, 47S-52S

[15] Thomas, KW, Dayton, CS dan W Peterson, M.W., 1999. Evaluation of Internet-Based Clinical Decision Support Systems. J Med Internet Res. 1.2, e6.

[16] Garg, A.X., Adhikari, N.K.J., McDonald, H., Neill K. J., Adhikari, McDonald, H., Arellano, M.P.R., Devereaux, P.J., Beyene, J., Sam, J. and Haynes B.R., 2005. Effects of computerized clinical decision support systems on practitioner performance and patient outcomes: a systematic review. JAMA;293, 10, 1223-38.

[17] Vadher B, Patterson, D L H, and Leaning, M., 1997. Evaluation of a decision support system for initiation and control of oral anticoagulation in a randromised trial. BMJ; 314:1252.

[18] Knab, J.H., Wallace, M.S., Wagner, R. L., Tsoukatos, J., and Weinger, M.B., 2001. The Use of a Computer-Based Decision Support System Facilitates Primary Care Physicians' Management of Chronic Pain. Anesth Analg; 93, 712-720

[19] Turban, Efraim, Aronson, J. E., Liang, Ting-Peng. (2005), Decision Support Systems and Intelligent Systems. International Edition, Edisi 7, New Jersey: Pearson Prentice-Hall Education International.

[20] Downtown., (1992). Engineering The Human-Computer Interface. McGraw-Hill book Company. London.

[21] Kusumadewi, S, dan Hartati, S. (2007). "Utilizing Fuzzy Multi-Attributr Decision Making for Group Clinical Decision Making Model", Proccedings of International Conference on Soft Computing, Intelligent System \& Information Technology (ICSIIT 2007), 18-24, UK Petra, Surabaya.

[22] Intan, R., Mukaidono, M., 2002. On Knowledge-based Fuzzy Sets. International Journal of Fuzzy Systems, 4.2 .

[23] Durkin, J, (1994). Expert Systems Design and Development, Prentice Hall.

[24] Weber, S.,2007. Clinical Decision Support Systems and How Critical Care Clinicians Use Them. Journal of Healthcare Information Management. 21. 2, 41-52 
[25] Murthy1, B. V. S., Lake S. P. dan Fisher, A. C., 2008. Evaluation of a decision support system to predict preoperative investigations. British Journal of Anaesthesia 100. 3, 315-21 